\title{
PENGARUH PENGGUNAAN AIR KONDESAT SEBAGAI MEDIA PRECOOLING KONDENSOR TERHADAP KINERJA SISTEM PENGKONDISIAN UDARA
}

\author{
Ragil Sukarno \\ Program Studi Pendidikan Teknik Mesin, Fakultas Teknik - Universitas Negeri Jakarta \\ Email : ragil-sukarno@unj.ac.id
}

\begin{abstract}
ABSTRAK
Pada sebuah sistem pengkondisi udara, terutama pada jenis AC split, air kondensat biasanya langsung dibuang dan belum dimanfaatkan. Sedangkan proses pelepasan panas pada kondensor membutuhkan fluida dingin untuk menurunkan panas. Tujuan dari penelitian ini adalah untuk memanfaatkan air kondensat untuk media pendinginan awalatau precooling pada kondensor dan melihat bagaimana pengaruhnya terhadap kinerja pengkondisian udara dalam bentuk coefficient of performance (COP). Metode pemanfaatan air kondensat untuk precooling pada kondensor ini adalah dengan mengalirkan air kondensat di sisi masuk kondensor dengan menggunakan metode distribusi air kondensat secara grafitasi. Dari hasil pengujian, didapatkan bahwa suhu udara masuk ke kondensor dengan menggunakan precooling menjadi lebih rendah rata-rata sebesar $1,30{ }^{\circ} \mathrm{C}$ bila dibandingkan dengan tanpa menggunakan precooling. Penggunaan precooling memberikan pengaruh terhadap peningkatan jumlah kalor yang dilepaskan kondensor dan peningkatan COP. Tanpa menggunakan precooling, pada pengujian 1 (suhue target $18^{\circ} \mathrm{C}$ ) COP adalah sebesar 4.58 , namun dengan menggunakan precooling, COP meningkat menjadi 4.71. Pada pengujian 2 ( suhue target $20^{\circ} \mathrm{C}$ ) COP adalah sebesar 4.65, namun dengan menggunakan precooling, COP meningkat menjadi 4.81. Sedangkan pada pengujian 3 ( suhue target $\left.22{ }^{\circ} \mathrm{C}\right)$ COP adalah 4.79, namun dengan menggunakan precooling, COP meningkat menjadi 4.86. Dari hasil analisis kinerja system pengkondisian udara dengan menggunakan precooling, didapatkan bahwa penggunaan air kondensat sebagai media precooling memberikan pengaruh positif terhadap peningkatan COP.
\end{abstract}

Kata Kunci: sistem pengkondisian udara, precooling, air kondensat, COP

\section{PENDAHULUAN}

Keterbatasan sumber energy dan dampak negative terhadap lingkungan saat ini menjadi perhatian yang sangat serius dalam skala global. Penggunaan sistem pengkondisian udara hamper merata di semua sektor, baik dalam sebuah bangunan komersial, perkantoran, atau perumahan, yang mana berfungsi untuk memberikan kenyamanan kepada penggunaanya. Pada sebuah bangunan komersial, konsumsi energi paling tinggi adalah digunakan untuk pengoperasian system pengkondisian udara. Dampak dari peningkatan konsumsi energi ini secara tidak langsung akan berdampak terhadap peningkatan emisi gas buang [1]. Sehingga langkah-langkah untukpenghematan energy dalam semua sector sangat penting untuk dilakukan, termasuk dalam system pengkondisin udara.

Pada sebuah bangunan perumahan atau sekolah-sekolah, jenis sistem pengkondisian udara yang digunakan sebagian besar adalah sistem AC split yang bekerja dengan sistem kompresi uap. Pada kondisi cuaca yang panas kinerja sistem pengkondisian udara window akan menurun dengan cepat dan konsumsi energi akan mengalami peningkatan[2]. Selain itu pada kondisi cuaca yang panas, penggunaan sistem pengkondisian udara juga akan meningkat, sehingga secara tidak langsung kebutuhan untuk pendinginan pada proses kondensasi juga akan meningkat. Suhu pendingin udara sangat tergantung pada suhu udara ambien, sehingga pada cuaca udara yang panas, suhu dan tekanan kondensor akan mengalami peningkatansebagai akibat dari peningkatan konsumsi energi dan peningkatan rasio tekanan pada kompresor. Untuk meningkatkan kinerja sebuah sistem pengkondisian udara, salah satu cara yang bisa dilakukan adalah dengan menurunkan suhu kondensor. Penurunan suhu kondensor akan menyebabkan penurunan rasio tekanan pada kompresor yang akan menghasilkan penurunan komsumsi pada system pengkondisian udara [3].

Dalam sistem pengkondisian udara terdapat dua proses perpindahan panas utama yaitu proses menyerap panas yang terjadi di evaporator dan proses membuang panas yang terjadi pada kondensor. Proses pemindahan panas pada sistem pengkondisi udara ini tentunya membutuhkan energi yang besar dari total energi yang dibutuhkan pada sistem pengkondisian udara. Penghematan energi dari proses perpindahan panas pada kedua sistem di evaporator dan kondensor ini menjadi tantangan yang harus diselesaikan. Pada sebuah sistem pengkondisi udara, terutama pada jenis AC split yang dipakai di perumahan, air kondensat biasanya langsung dibuang dan belum dimanfaatkan. Sedangkan proses pembuangan panas pada kondensor 
membutuhkan fluida dingin untuk menurunkan panas. Oleh karena itu perlu dilakukan pemanfaatan air kondensat ini untuk proses precooling pada kondensor sehingga penghematan energi bisa didapatkan.

Penelitian-penelitian untuk meningkatkan kinerja sebuah sistem pengkondisian udara dengan memanfaatkan air kondensat sudah mulai dilakukan. E. Hajidavalloo (2007), melakukan penelitian untuk meningkatkan kinerja sistem pengkondisian udara tie window dengan meningkatkan laju perpindahan kalor dalam kondensor dengan meletakkan dua cooling pad pada dua sisi sistem pengkondisian udara dan menyemprotkan dengan air. Dari hasil penelitian menunjukkan bahwa konsumsi udara menurun sekitar $16 \%$ dan coefficient of performance(COP) meningkat sebesar 55\% [2].E. Hajidavalloo dan H. Eghte dari (2010) melakukan dengan menambahkan evaporative cooler pada sisi pendingin udara kondensor dengan tujuan meningkatkan kinerja dari siklus system pengkondisian udara pada suhu udara ambient mencapai $49{ }^{\circ} \mathrm{C}$. Dari hasil pengujian didapatkan bahwa konsumsi udara menurun sekitar 20\% dan COP meningkat sebesar $50 \%$ [3]. Xun Zhu, Jun-JunWu, et al(2015), melakukan penelitian dengan memanfaatkan air kondensat dingin yang digunakan untuk mendinginkan kondensor dengan menggunakan metode penyemprotan. Air kondensor menjadi gelembung-gelembung setelah disemprot dari sebuah nosel. Gelembung air tersebut disemprotkan langsung ke sirip-sirip alat penukar kalor kondensor. Hasil penelitian ini menunjukkan bahwa terjadi peningkatan penghematan energi dan peningkatan COP pada pengoperasian pendinginan condenser [4]. Shahid Ali Khan, et al. (2014) melakukan penelitian dengan melakukan pendinginan awal pada kondensor dengan menggunakan kondensat. Dari hasil penelitian menunjukkan bahwa penghematan kapasitas pendinginan mencapai $15 \%$ dan penghematan konsumsi energi mencapai $18 \%$ [5].

Dari beberapa literature yang telah dilakukan dapatd ilihat bahwa peralatan sederhana, efektifitas, penghematan energi dan keuntungan dari sisi ekonomi menjadi keuntungan dari penerapan metode ini. Dengan memanfaatkan air kondensat yang suhunya lebih rendah daripada suhu udara luar, maka diharapkan suhu udara yang masuk sebelum ke kondensor. Sehingga secara keseluruhan proses perpindahan kalor pada kondensor menjadi lebih cepat dan penghematan energi bisa didapatkan. Suhu udara ruang yang tidak selalu sama menjadi hal yang harus diperhatikan pada proses precooling ini. Sehingga penggunaan air kondensat sebagai media pendingin awal proses kondensasi juga perlu dilakukan.

Peluang untuk menggunakan air kondensat sebagai pendingin awal udara yang akan masuk ke kondensor sangat besar, karena konsumsi air pada sistem ini adalah sangat kecil dan resiko kerusakan terhadap tabung-tabung kondensor juga sangat rendah karena tidak ada kontak langsung antara air dengan tabung dari kondensor. [3].

Berdasarkan latar belakang diatas, maka dalam penelitian ini akan dilakukanpemanfaatan air kondensat sebagai media pendinginan awal atau proses precooling suhu udara sebelum masuk ke kondensor pada sistem pengkondisian udara (AC) tipe split" dengan menggunakan metode distribusi secara grafitasi.

\section{TUJUAN PENELITIAN}

Tujuan dari penelitian ini adalah untuk meningkatkan kinerja sistem pengkondisian udara dengan memanfaatkan air kondensat sebagai media precoolingudara sebelum masuk ke kondensor. 


\section{METODE PENELITIAN}

Langkah-langkah yang dilakukan dalam melaksanakan penelitian ini bisa ditunjukkan pada gambar berikut ini.

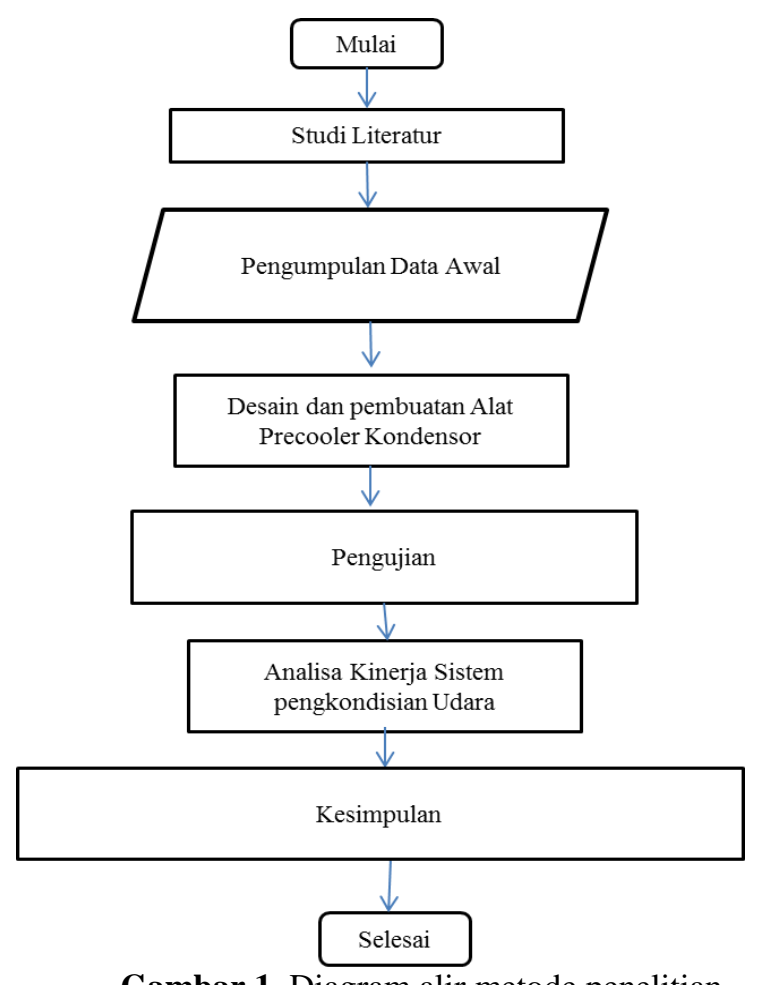

Gambar 1. Diagram alir metode penelitian

Pada penelitian ini, proses pendinginan awal atau precooling adalah dengan mengalirkan air kondensat kesisi depan kondensor secara langsung dengan metode grafitasi. Sehingga suhu udara yang akan masuk kekondensor diharapkan akan turun. Sistem pengkondisian udara yang digunakan dalam penelitian ini adalah AC tiple Split $1 / 2$ PK.

Skematik dari rencana pengembangan system pengkondisian udara ditunjukkan seperti pada gambar 2.

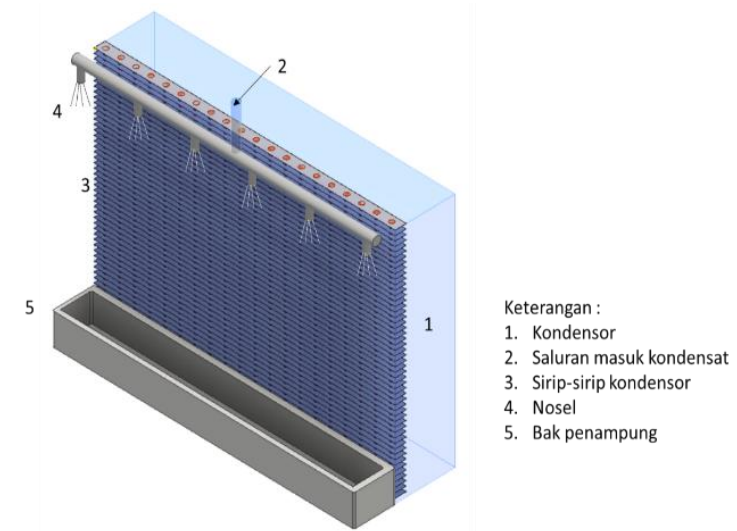

Gambar 2. Skematik pemasangan alat precooling kondensor 
Sedangkan skematik pengujian ditunjukkan pada gambar 3.

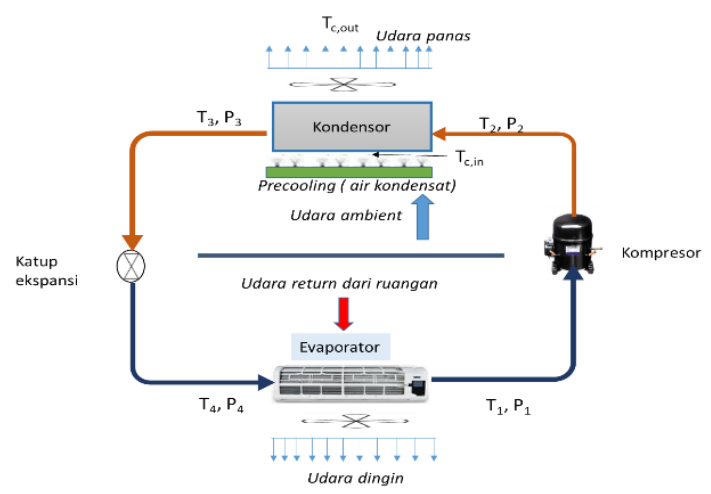

Gambar 3. Skematik pengujian sistem ac dengan dilengkapi precooler kondensor

\section{HASIL DAN PEMBAHASAN}

Pada pengujian yang dilakukan, suhu ambient berkisar pada $31{ }^{\circ} \mathrm{C}-32{ }^{\circ} \mathrm{C}$ baik saat pengujian tanpa menggunakan precooling atau saat menggunakan precooling.Dan suhu air kondensat adalah pada $28^{\circ} \mathrm{C}$.Dengan adanya precooling, suhu udara masuk kondensor menjadi berkurang seperti diperlihatkan pada gambar 4.1. Tanpa menggunakanprecooling, pada pengujian 1 (suhu target $18^{\circ} \mathrm{C}$ ) suhu udara masuk adalah $30,78{ }^{\circ} \mathrm{C}$, namun dengan menggunakan precooling, suhu udara masuk kondensor berkurang menjadi 29.38 ${ }^{\circ} \mathrm{C}$. Pada pengujian 2 (suhu target $20{ }^{\circ} \mathrm{C}$ ) suhu udara masuk adalah $31.38{ }^{\circ} \mathrm{C}$, namun dengan menggunakan precooling, suhu udara masuk kondensor berkurang menjadi $30.04{ }^{\circ} \mathrm{C}$. Sedangkan pada pengujian 3 ( suhu target $22{ }^{\circ} \mathrm{C}$ ) suhu udara masuk adalah $31.70{ }^{\circ} \mathrm{C}$, namun dengan menggunakan precooling, suhu udara masuk kondensor berkurang menjadi $30.42{ }^{\circ} \mathrm{C}$. Dari gambar 3 ini terlihat bahwa dengan menggunakan precooling, didapatkan penurunan suhu udara masuk ke kondensor rata-rata sebesar $1.30^{\circ} \mathrm{C}$.

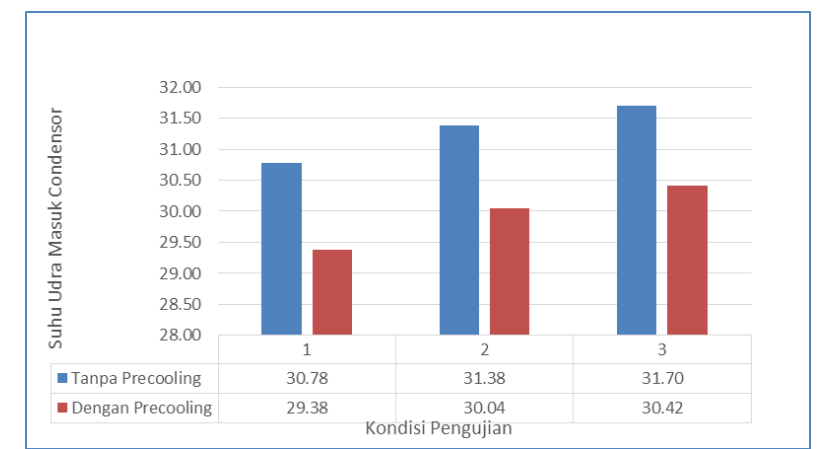

Gambar 4. Suhu udara masuk kondensor

Pengaruh penggunaan air kondensat sebagai media precooling terhadap laju pelepasan kalor diperlihatkan pada gambar 5.

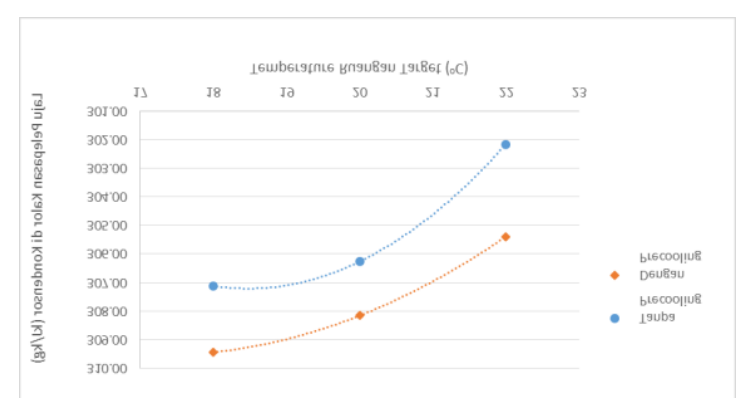

Gambar 5. Hubungan suhu target dan laju pelepasan kalor di kondensor

Dari gambar 5 diperlihatkan bahwa dengan menggunakan precooling, kalor yang dilepaskan oleh kondensor lebih tinggi dibandingkan tanpa menggunakan precooling. Ini memperlihatkan bahwa penggunaan 
kondensat memberikan pengaruh yang positif terhadap penurunan suhu awal udara yang akan masuk ke kondonsor.

Pada gambar 6 memperlihatkan hubungan suhu target dengan COP pada sistem pendingin yang tanpa menggunakan precoolingdan menggunakan precoolingpada kondensor.

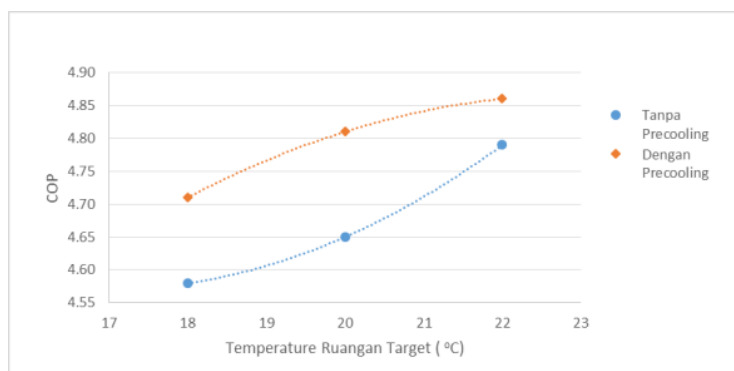

Gambar 6. Hubungan suhu target dengan kinerja Sistem pengkondisian udara (COP)

Dari gambar 6 memperlihatkan bahwa semakin tinggi suhu target, maka beban dari kompresor menjadi lebih rendah, sehingga COP menjadi lebih tinggi. Dengan menggunakan precooling, kalor yang dilepaskan lebih besar sehinggan COP dengan menggunakan precoolinglebih tinggi dibandingkan sistem pengkondisian udara yang tanpa menggunakan precooling.

Tanpa menggunakan precooling, pada pengujian 1 ( suhu target $18{ }^{\circ} \mathrm{C}$ ) COP adalah 4.58 , namun dengan menggunakan precooling, COP meningkat menjadi 4.71. Pada pengujian 2 ( suhu target $20{ }^{\circ} \mathrm{C}$ ) $\mathrm{COP}$ adalah 4.65, namun dengan menggunakan precooling, COP meningkat menjadi 4.81. Sedangkan pada pengujian 3 ( suhu target $22{ }^{\circ} \mathrm{C}$ ) COP adalah 4.79, namun dengan menggunakan precooling, COP meningkat menjadi 44.86. Dari gambar 5.3 ini terlihat bahwa dengan menggunakan precooling, didapatkan peningkatan COP rata-rata sebesar 0,10 .

Dari pembahasan sebelumnya terlihat bahwa air kondensat yang biasanya terbuang bisa dimanfaatkan kembali sebagai pendingin awal sebelum dibuang. Dengan laju volume massa air kondensat sebesar 0,02 liter/menit, mampu memberikan pengaruh yang positif terhadap peningkatan kinerja dari sistem pengkondisian udara.

\section{KESIMPULAN}

Berdasarkan hasil analisa dan pembahasan pada bab sebelumnya dapat disimpulkan sebagai berikut :

1. Pemanfaatan air kondensat sebagai media pendingin awal memberikan pengaruh yang positif terhadap kinerja sistem pengkondisian udara. Suhu udara masuk ke kondensor dengan menggunakan precoolingmenjadi lebih rendah rata-rata sebesar $1,30^{\circ} \mathrm{C}$ bila dibandingkan dengan tanpa menggunakan precooling.

2. Penggunaan precoolingmemberikan pengaruh terhadap peningkatan jumlah kalor yang dilepaskan kondensor bila dibandingkan tanpa menggunakan precooling.

3. Tanpa menggunakan precooling, pada pengujian 1 ( suhu target $18{ }^{\circ} \mathrm{C}$ ) $\mathrm{COP}$ adalah 4.58 , namun dengan menggunakan precooling, COP meningkat menjadi 4.71. Pada pengujian 2 ( suhu target $20{ }^{\circ} \mathrm{C}$ ) $\mathrm{COP}$ adalah 4.65, namun dengan menggunakan precooling, COP meningkat menjadi 4.81. Sedangkan pada pengujian 3 ( suhu target $22{ }^{\circ} \mathrm{C}$ ) $\mathrm{COP}$ adalah 4.79, namun dengan menggunakan precooling, $\mathrm{COP}$ meningkat menjadi 44.86. Secara keseluruhan dapatdilihat bahwa dengan menggunakan precooling, didapatkan peningkatan COP rata-rata sebesar 0,10.

4. Desain alat distribusi air kondensat dengan menggunakan metode grafitasi telah memberikan pengaruh yang positif terhadap kinerja sistem pengkondisian udara dengan peningkatan COP sebesar 0,10.

\section{DAFTAR PUSTAKA}

1. Vahid Vakiloroaya, et al,A review of different strategies for HVAC energy saving, Energy Conversion and Management Journal, 2017.77:p. 738-754.

2. E. Hajidavalloo, Application of evaporative cooling on the condenser of window-air-conditioner, Applied Thermal Engineering, 2007.27: p.1937-1943

3. E. Hajidavalloo \& H.Eghtedari, Performance improvement of air-cooled refrigeration system by using evaporatively cooled air condenser, International Journal of Referigeration 2010.33: p.982-988

4. Xun Zhu, Jun-jun Wu, Bin Lin, YU Tan, Cheng-cheng Huang, Hua Li, Lei Cao, Ze-jun Liu, Airconditioning condenser integrated with a spray system utilizing condensate water, UDC: 621.5, 2015 
5. Khan, Shahid Ali; Wang, Fan; Al-Zubaidy, Sarim, Energy Recovery Through the Condensate of Air Conditioning Machines, International Journal of Engineering Research and Technology, 2014

6. C.P Arora, Refrigeration and Sistem Conditioning, second edition, McGraw-Hill, 2006

7. Shan K. Wang, Handbook Of Air Conditioning And Refrigeration, Second Edition, McGraw-Hill, 2000

8. ASHRAE, HVAC Fundamental Handbook, 1997 